\title{
LETTER
}

\section{Feldspar in felsic orthogneiss as indicator for UHT crustal processes}

\author{
Tomokazu HoKADA ${ }^{*, * *}$ and Satoko SUZUKI ${ }^{* * *}$ \\ *National Institute of Polar Research; 1-9-10 Kaga, Itabashi, Tokyo 173-8515, Japan \\ **: Department of Polar Science, The Graduate University for Advanced Studies; \\ 1-9-10 Kaga, Itabashi, Tokyo 173-8515, Japan \\ ***: Center for Chronological Research, Nagoya University, \\ Furo-cho, Chikusa, Nagoya, 464-8602, Japan
}

\begin{abstract}
Felsic orthogneisses with tonalitic and granodioritic compositions are dominant in the ultrahigh-temperature (UHT) metamorphic terrane of the Archaean-early Proterozoic Napier Complex, East Antarctica. Antiperthitic or mesoperthitic ternary feldspar occurs in addition to Qtz, Opx with/without Cpx in these felsic orthogneisses. Such feldspar grains commonly display zonal structure with respect to the volume of exsolution lamella; lamellae-enriched core and lamellae-free rim. Pre-exsolution one-phase compositions have been recovered separately for the feldspar core (an:ab:or $=20-28: 53-56: 17-28$ in tonalitic samples and an:ab:or $=15-17: 37-$ 48:36-48 in granodioritic samples) and for the whole feldspar grain (an:ab:or $=24-29: 58-63: 13$ in tonalitic samples and an:ab:or $=18-20: 45-56: 24-37$ in granodioritic samples). Application of feldspar thermometry for these recovered one-phase compositions and the feldspar cores yield a temperature range of $940-1100{ }^{\circ} \mathrm{C}$, which is relatively higher temperatures than the whole feldspar grain giving $>850-1070{ }^{\circ} \mathrm{C}$. These compositional differences between core and rim of single feldspar grains are probably due to either sub-solidus or meltrelated processes. The compositional and textural information of ternary feldspars in felsic orthogneisses can be therefore potential tools for understanding UHT crustal processes.
\end{abstract}

Keywords: Antarctica, Feldspar, Napier Complex, Orthogneiss, Ultrahigh temperature/UHT

\section{INTRODUCTION}

Felsic orthogneiss is a common constituent in various granulite-facies terranes. Because of its relatively simple mineral assemblage, which is stable over a wide $P-T$ range, such gneisses have not been regarded as a useful lithology for estimating metamorphic conditions and processes. The protolith of the felsic orthogneisses are in many cases regarded as igneous rocks whose geochemical characteristics are useful for evaluating the original magmas. However, less attention has been paid to the effects of the compositional modification, even if minor, during the high-grade metamorphism. In view of felsic orthogneisses occupying such a large proportion of high-grade metamorphic terranes, a tool to investigate their metamorphic and chemical processes should be needed. This study proposes feldspar mineral texture and composition to use for discussing the high-grade metamorphic processes including the chemical behavior controlled by fluid and/or

doi:10.2465/jmps. 101.260

T. Hokada, hokada@nipr.ac.jp Corresponding author partial melting.

Feldspar geothermometry has been applied to estimate the peak metamorphic conditions, especially $>900$ ${ }^{\circ} \mathrm{C}$ ultrahigh-temperature (UHT) conditions has been recovered by the ternary feldspar solvus models applying to re-integrated pre-exsolution one phase composition of perthitic, antiperthitic and mesoperthitic ternary feldspar (e.g., Hokada, 2001). This technique is particularly useful for rocks without any other reliable mineral assemblages to estimate the metamorphic temperatures. A concern of this technique is that the distribution of exsolution lamellae within a single feldspar crystal is not always homogeneous. They are commonly concentrated in the crystal core. Lamellae-free rims are occasionally observed in such feldspar crystal, and are usually thought to be formed by later modification. It may be possible that these compositional modifications were controlled by the fluid and/or melt-related processes during the post-peak stage of HT-UHT metamorphism. 


\section{GEOLOGICAL BACKGROUND AND SAMPLE DESCRIPTION}

Six felsic orthogneiss samples used in this study were collected from the Mt. Riiser-Larsen area within the UHT zone of the late Archaean - early Proterozoic granulite terrane of the Napier Complex (Fig. 1). Felsic orthogneisses are dominant in the area, and are roughly classified into tonalitic and granodioritic compositions (Suzuki et al., 1999). Peak metamorphic conditions in this area were estimated to be $>1100{ }^{\circ} \mathrm{C}$ (e.g., Harley and Motoyoshi, 2000; Hokada, 2001). The felsic orthogneisses have been completely recrystallized at such UHT conditions and contain the anhydrous mineral assemblage of quartz + antiperthite + orthopyroxene + clinopyroxene for tonalitic samples (sp. SS97012101, SS97011505, SS97011304) and quartz + mesoperthite + orthopyroxene for granodioritic samples (sp. SS97021102, SS97012401, SS97020402). Magnetite, ilmenite, apatite and zircon are minor. Quartz, feldspars and pyroxenes show granoblastic textures and typically lack alignment of the crystals. Fine monazite grains $(<10 \mu \mathrm{m})$ are occasionally found within or around apatite crystals.

Textural differences between antiperthite and mesoperthite are shown in Figure 2. Needles or rods of 20-50 $\mu \mathrm{m}$ diameter are developed as exsolution lamellae in antiperthite, whereas thin plates of less than $10 \mu \mathrm{m}$ thickness comprise the lamellae of mesoperthite. For both antiper- thite and mesoperthite, exsolutuion lamellae are commonly restricted to the cores of feldspar grains, whereas a lamella-free area less than $100 \mu \mathrm{m}$ wide, is developed at the rim. No significant compositional differences between lamella-free rim and the host part in the lamellae-rich core can be seen.

\section{ANALYTICAL TECHNIQUE}

Host and lamellae compositions of antiperthitic and mesoperthitic feldspars in orthogneiss samples were obtained using electron microprobe JEOL JXA-8200 equipped with 5ch WDS at the National Institute of Polar Research. Pre-exsolution one-phase feldspar compositions, which can be indicative of peak metamorphism, were estimated using the method described in Kroll et al. (1993) and Hokada (2001). Area proportions of host and lamellae domains were estimated based on X-ray intensity mapping of $\mathrm{Na}$ and $\mathrm{K}$ (Fig. 2b, c, e, f), and were converted to a weight ratio using densities $\left(2.67 \mathrm{~g} / \mathrm{cm}^{3}\right.$ for plagioclase and $2.57 \mathrm{~g} / \mathrm{cm}^{3}$ for alkali feldspar, respectively). To assess the compositional variation within single crystals, such as lamellae-rich core and lamellae-free rim, pre-exsolution one-phase original compositions have been calculated separately for feldspar whole-grain (w) and for core (c) where exsolution lamellae is concentrated. The results are given in Table 1.

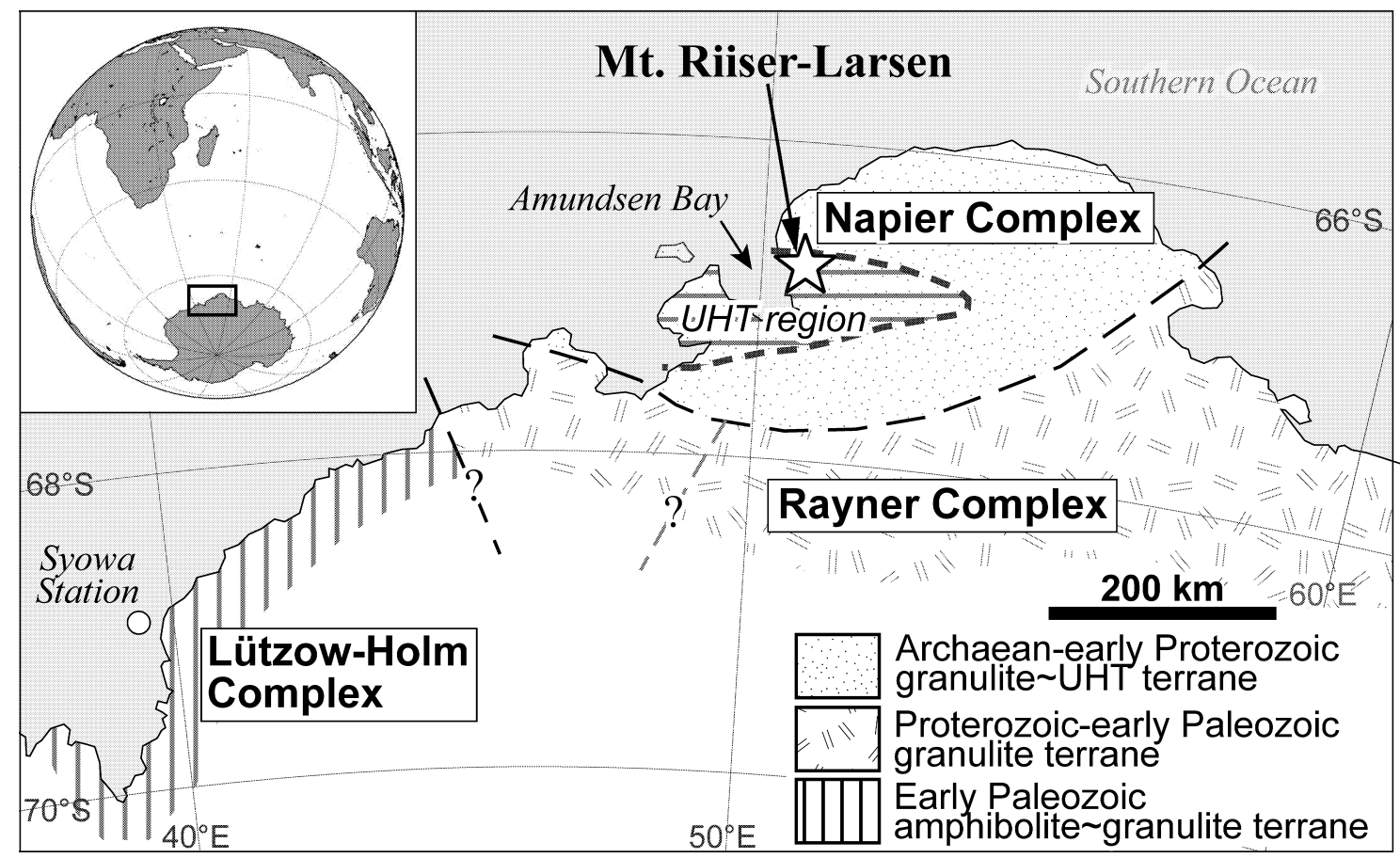

Figure 1. Geological outline of the Napier Complex and surrounding area in East Antarctica (after Harley and Hensen, 1990), and location of the Mt. Riiser-Larsen area. 


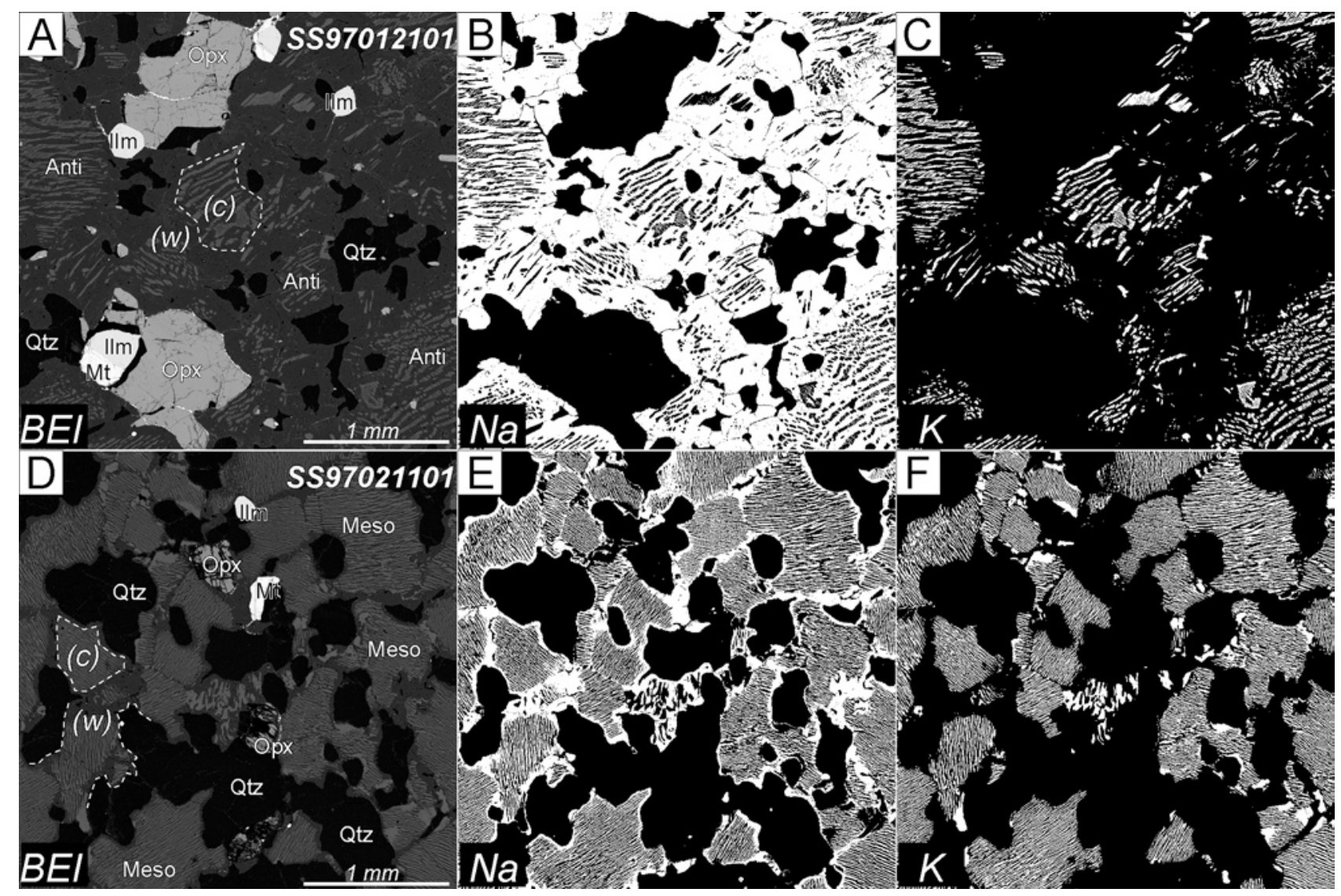

Figure 2. Backscattered-electron image (BEI) and two-valued X-ray intensity map (Na and K) of tonalitic [(a) (b) (c); sp. SS97012101] and granodioritic [(d) (e) (f); sp. SS97021102] felsic orthogneiss samples from the Mt. Riiser-Larsen area. Mineral abbreviations follow Kretz (1983) except Anti: antiperthite and Meso: mesoperthite. It is noted that exsolution lamellae are concentrated in the core of feldspar grain, and the recovery of pre-exsolution one-phase feldspar composition has been applied for the following two different areas; (1) lamellae concentrated core [labeled '(c)'] and (2) whole feldspar grain including lamellae-bearing core and lamellae-free rim [labeled '(w)'].

\section{RESULTS AND DISCUSSION}

Antiperthite in three 'tonalitic' samples have pre-exsolution compositions of feldspar core (an:ab:or $=20-28$ :5356:17-28) and whole grain compositions of (an:ab:or $=$ 24-29:58-63:13). Mesoperthite in three 'granodioritic' samples have pre-exsolution compositions of core (an:ab:or $=15-17: 37-48: 36-48)$ and whole grain (an:ab:or $=18-20: 45-56: 24-37$ ) (Fig. 3). Several models of the ternary feldspar solvus (Fuhrman and Lindsley, 1988; Lindsley and Nekvasil, 1989; Elkins and Grove, 1990) suggest that these recovered feldspar compositions were stable at over $940-1100{ }^{\circ} \mathrm{C}$ for core (c) and $850-1070{ }^{\circ} \mathrm{C}$ for whole-grain $(\mathrm{w})$ except for the extremely high temperatures $\left(\sim 1170{ }^{\circ} \mathrm{C}\right)$ calculated by the model of Elkins and Grove (1990). These estimated temperatures (at least $850^{\circ} \mathrm{C}$ up to $1100^{\circ} \mathrm{C}$ ), which correspond to the minimum peak temperatures recorded in the examined felsic orthogneiss, are consistent with the previously reported peak metamorphic conditions in the Mt. Riiser-Larsen area (e.g., Harley and Motoyoshi, 2000; Hokada, 2001).

Feldspar crystals constitute large proportion of the rocks, and the formation of ternary one-phase feldspar replacing the pre-existing plagioclase-alkali feldspar pairs needs extensive recrystallization during UHT metamorphism. Such pervasive recrystallzation might have happened with melt-present processes in such high temperature conditions, nevertheless no obvious petrographic evidence such as migamtitic structure or euhedral crystal shape or zonal structure which can be indicative of the presence of the melt during metamorphism, cannot be seen in these rocks. Differences between recovered onephase feldspar core and whole grain compositions reported here are keys for understanding the process to crystallize ternary feldspar in UHT conditions.

When taking into account the results of feldspar cores giving higher temperatures than feldspar wholegrain, the mechanisms may be related with one (or some) of the following possibilities: (1) Feldspar core-rim variation records original growth compositional zoning with 
Table 1. Estimation of re-integrated one-phase compositions of antiperthitic and mesoperthitic feldspars in felsic orthogneiss, and geothermometry for these pre-exsolution feldspar compositions

\begin{tabular}{|c|c|c|c|c|c|c|c|c|c|c|c|c|c|}
\hline \multirow{3}{*}{ Sample No. } & \multirow{3}{*}{$\begin{array}{l}\text { Rock } \\
\text { type }\end{array}$} & \multirow{3}{*}{ Area } & \multirow{2}{*}{\multicolumn{2}{|c|}{$\begin{array}{l}\text { Area (volume) } \\
\text { proportion [\%] }\end{array}$}} & \multicolumn{2}{|c|}{ Weight ratio [\%] } & \multirow{2}{*}{\multicolumn{3}{|c|}{$\begin{array}{c}\text { Re-integrated } \\
\text { composition [molar ratio] }\end{array}$}} & \multicolumn{4}{|c|}{ Geothermometry } \\
\hline & & & & & \multirow{2}{*}{$\begin{array}{c}\text { Pl } \\
\text { Host }\end{array}$} & \multirow{2}{*}{$\begin{array}{c}\text { Kfs } \\
\text { Lamellae }\end{array}$} & & & & \multirow{2}{*}{$\begin{array}{l}\mathrm{T}(\mathrm{FL}) \\
{\left[{ }^{\circ} \mathrm{C}\right]}\end{array}$} & \multirow{2}{*}{$\begin{array}{c}\mathrm{T}\left(\mathrm{FL}^{*}\right) \\
{\left[{ }^{\circ} \mathrm{C}\right]}\end{array}$} & \multirow{2}{*}{$\begin{array}{c}\mathrm{T}(\mathrm{LN}) \\
{\left[{ }^{\circ} \mathrm{C}\right]}\end{array}$} & \multirow{2}{*}{$\begin{array}{c}\mathrm{T}(\mathrm{EG}) \\
{\left[{ }^{\circ} \mathrm{C}\right]}\end{array}$} \\
\hline & & & $\mathrm{Na}$ & $\mathrm{K}$ & & & An & $\mathrm{Ab}$ & Or & & & & \\
\hline \multirow[t]{2}{*}{ SS97012101 } & $\mathrm{T}$ & W & 86.3 & 13.7 & 86.7 & 13.3 & 0.242 & 0.630 & 0.128 & 870 & 866 & 853 & 888 \\
\hline & & $\mathrm{C}$ & 69.8 & 30.2 & 70.6 & 29.4 & 0.197 & 0.528 & 0.275 & 1015 & 1027 & 1012 & 1067 \\
\hline \multirow[t]{2}{*}{ SS97011505 } & $\mathrm{T}$ & W & 87.6 & 12.4 & 88.0 & 12.0 & 0.289 & 0.578 & 0.133 & 902 & 894 & 897 & 940 \\
\hline & & $\mathrm{C}$ & 84.0 & 16.0 & 84.5 & 15.5 & 0.278 & 0.557 & 0.165 & 949 & 944 & 948 & 996 \\
\hline \multirow[t]{2}{*}{ SS97011304 } & $\mathrm{T}$ & W & 87.6 & 12.4 & 88.0 & 12.0 & 0.277 & 0.591 & 0.132 & 895 & 888 & 886 & 927 \\
\hline & & $\mathrm{C}$ & 82.0 & 18.0 & 82.5 & 17.5 & 0.260 & 0.557 & 0.183 & 964 & 963 & 963 & 1011 \\
\hline \multirow[t]{2}{*}{ SS97021102 } & GD & W & 60.7 & 39.3 & 61.6 & 38.4 & 0.179 & 0.447 & 0.374 & 1060 & 1085 & 1066 & 1144 \\
\hline & & C & 49.2 & 50.8 & 50.1 & 49.9 & 0.146 & 0.373 & 0.481 & 1062 & 1105 & 1070 & 1168 \\
\hline \multirow[t]{2}{*}{ SS97012401 } & GD & W & 73.9 & 26.1 & 74.7 & 25.3 & 0.199 & 0.560 & 0.241 & 988 & 996 & 980 & 1027 \\
\hline & & $\mathrm{C}$ & 61.1 & 38.9 & 62.0 & 38.0 & 0.166 & 0.476 & 0.358 & 1039 & 1062 & 1038 & 1104 \\
\hline \multirow[t]{2}{*}{ SS97020402 } & GD & W & 66.3 & 33.7 & 67.2 & 32.8 & 0.204 & 0.481 & 0.315 & 1050 & 1066 & 1056 & 1124 \\
\hline & & $\mathrm{C}$ & 54.8 & 45.2 & 55.8 & 44.2 & 0.169 & 0.410 & 0.421 & 1070 & 1103 & 1079 & 1169 \\
\hline
\end{tabular}

$\mathrm{T}$, tonalitic (Qtz + antiperthite + Opx with minor Cpx); GD, granodioritic (Qtz + mesoperthite + Opx).

$\mathrm{W}$, whole feldspar grain; $\mathrm{C}$, feldspar core.

T(FL), Fuhrman and Lindsley (1988) corrected by Kroll et al. (1993); T(LN), Lindsley and Nekvasil (1989); T(EG), Elkins and Grove (1990).

$\mathrm{T}\left(\mathrm{FL}^{*}\right)$, Fuhrman and Lindsley (1988) with Margules parameters $\mathrm{W}_{\mathrm{AnOr}}$ and $\mathrm{W}_{\text {OrAn }}$ interchanged.

It should be noted that the values of $\mathrm{W}_{\mathrm{AnOr}}$ and $\mathrm{W}_{\text {OrAn }}$ in Fuhrman and Lindlsey (1988) should be interchanged as pointed out by Kroll et al. (1993), and the temperature estimates using these wrong interchanged $\mathrm{W}$ values are also given in this table [T(FL $\left.{ }^{*}\right)$ ] for comparison purpose because Hokada (2001) has applied feldspar thermometry using these wrong interchanged values.
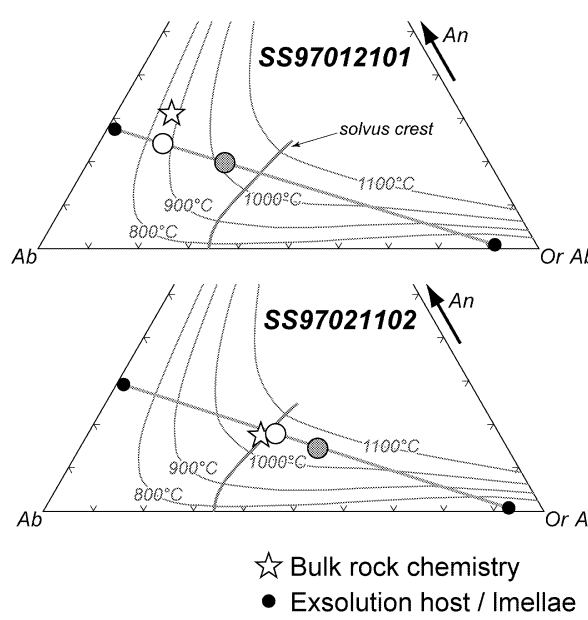
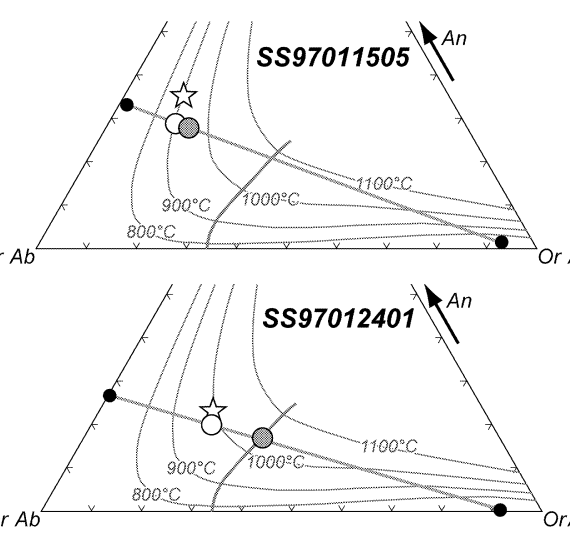

Re-integrated pre-exsolution one phase feldspar composition
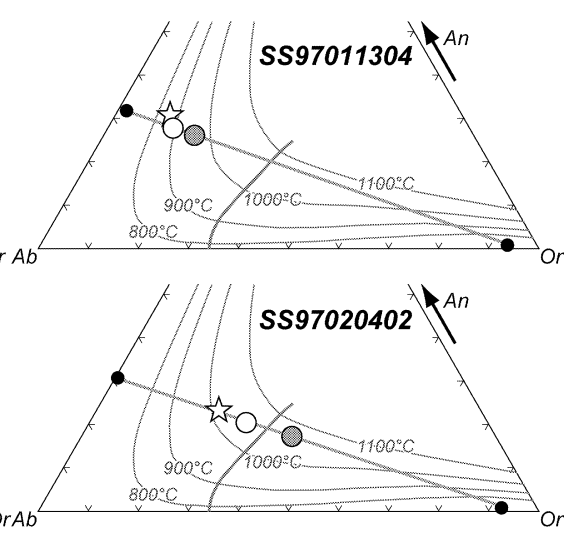

Feldspar whole grain (w)

Feldspar core (c)

Figure 3. Ternary plots of feldspar compositions along with re-integrated recovered one-phase feldspar compositions. Solvus curves are calculated at $0.8 \mathrm{GPa}$ using the model of Fuhrman and Lindsley (1988).

temperature drop, and, hence, the lamella-free (orthoclase-poor) rim is the retrograde product post-dating the core formation at the metamorphic peak. However, any metamorphic reactions to form this texture is not reliable because no other obvious retrograde phase to be equilibrated with the lamellae-free rims has been observed in the rock. (2) Feldspar grains were originally homogeneous at the peak of metamorphism, and the lamella-free rim later formed by inter-crystalline diffusion during cooling. Precipitation of exsolution lamellae within the host crystal during cooling is largely controlled by the effective distance of intracrystalline diffusion, and it may be possible that nucleation of exsolution lamellae is prohibited at the area close to the grain edge where lamellae component can be easily diffused away toward the outside of the host crystal to precipitate an independent crystal. In this case, the width of lamella-free (orthoclasepoor) rim is controlled by the diffusion kinetics of orthoclase component in ternary feldspar. (3) Fluid-related process to remove $\mathrm{K}_{2} \mathrm{O}$ component in the rim of feldspar grains (dissolution of pre-existing ternary feldspar and re-precipitation of low- $\mathrm{K}_{2} \mathrm{O}$ feldspar) caused by the infil- 
tration of fluid along grain boundary may be possible. This is, however, not supported by petrographical evidence suggesting the infiltration of fluid in the rock. (4) Ternary feldspar crystals may have been precipitated from partial melt during UHT metamorphism, and the change of feldspar composition from core to rim is controlled by or the function of the coexisting melt compositions. Although no obvious petrographic evidence to suggest the presence of partial melt during metamorphism can be seen in the rock as discussed above, it is quite possible for quartzo-feldspathic rocks to be partially molten at such high metamorphic temperatures as up to $1100{ }^{\circ} \mathrm{C}$ even in the dry condition. Discrete processes and conditions to generate partial melt under UHT conditions and to precipitate ternary feldspars in the presence of melt in these rocks are beyond the scope of this paper, but they should be important targets to be assessed by the future study.

Finally, it is not easy to assess the reliability of the above four possibilities by the currently available data, the compositional and textural information of these ternary feldspars in felsic orthogneisses can be potential tools for understanding UHT crustal processes.

\section{ACKNOWLEDGMENTS}

Samples used in this study were collected during the 1996-1997 Japanese Antarctic Research Expedition (JARE), and the members of JARE, especially Professor H. Ishizuka and Dr. M. Ishikawa are thanked for their co $^{-}$ operation during the field work. Constructive reviews by Drs. T. Okudaira and T. Tsunogae and comments made by Prof. D.J. Ellis improved the manuscript, and thanks are also due to them. This study was financially supported by a Grant-in-Aid for Scientific Research to TH from the Ministry of Education, Culture, Sports, Science and Tech- nology No.16740298.

\section{REFERENCES}

Elkins, L.T. and Grove, T.L. (1990) Ternary feldspar experiments and thermodynamic models. American Mineralogist, 75, 544-559.

Fuhrman, M.L. and Lindsley, D.H. (1988) Ternary feldspar modeling and thermometry. American Mineralogist, 73, 201-215.

Harley, S.L. and Hensen, B.J. (1990) Archaean Proterozoic highgrade terranes of East Antarctica $\left(40-80^{\circ} \mathrm{E}\right)$ : a case study of diversity in granulite facies metamorphism. In High-Temperature Metamorphism and Crustal Anatexis (Ashworth, J.R. and Brown, M. Eds.). Unwin Hyman, London, 320-370.

Harley, S.L. and Motoyoshi, Y. (2000) Al zoning in orthopyroxene in a sapphirine quartzite: evidence for $1120{ }^{\circ} \mathrm{C}$ UHT metamorphism in the Napier Complex, Antarctica, and implications for the entropy of sapphirine. Contributions to Mineralogy and Petrology, 138, 293-307.

Hokada, T. (2001) Feldspar thermometry in ultrahigh-temperature metamorphic rocks: evidence of crustal metamorphism attaining $\sim 1100^{\circ} \mathrm{C}$ in the Archaean Napier Complex, East Antarctica. American Mineralogist, 86, 932-938.

Kretz, R. (1983) Symbols for rock-forming minerals. American Mineralogist, 68, 277-279.

Kroll, H., Evangelakakis, C. and Voll, G. (1993) Two-feldspar geothermometry: a review and revision for slowly cooled rocks. Contributions to Mineralogy and Petrology, 114, 510518.

Lindsley, D.H. and Nekvasil, H. (1989) A ternary feldspar model for all reasons. EOS Transaction American Geophysical Union, 70, 506.

Suzuki, S., Hokada, T., Ishikawa, M and Ishizuka, H. (1999) Geochemical study of granulites from Mt. Riiser-Larsen, Enderby Land, East Antarctica: implications for protolith of the Archaean Napier Complex. Polar Geoscience, 12, 101125.

Manuscript received June 20, 2006

Manuscript accepted July 12, 2006

Manuscript handled by M. Santosh 